\title{
Measuring Populist Attitudes on Three Dimensions
}

\section{Anne Schulz ${ }^{\mathrm{I}}$, Philipp Müller ${ }^{2}$, Christian Schemer ${ }^{2}$, Dominique Stefanie Wirz ${ }^{\mathrm{I}}$, Martin Wettstein ${ }^{\mathrm{I}}$, and Werner Wirth ${ }^{\mathrm{I}}$}

\begin{abstract}
${ }^{\mathrm{I}}$ Institute of Mass Communication and Media Research, University of Zurich, Switzerland; ${ }^{2}$ Department of Communication; Johannes Gutenberg University of Mainz, Germany
\end{abstract}

\begin{abstract}
Theoretically, populism has been conceptualized as a political ideology with three subdimensions: anti-elitism attitudes, a preference for popular sovereignty, and a belief in the homogeneity and virtuousness of the people. However, empirical research to date has treated populist attitudes as a unidimensional construct. To address this issue, we propose to conceptualize populist attitudes as a latent higher-order construct with three distinct first-order dimensions. A I2-item inventory was developed using two survey studies conducted in Switzerland in 2014 and 20I5. Exploratory and confirmatory factor analyses were used to test the construct validity of this measure of populist attitudes. The measurement that is proposed allows for a fine-grained study of populist attitudes in the general public.
\end{abstract}

In the national elections of 20I4, 20I5, and 20I6, the citizens of European countries such as Sweden, Finland, Poland, Denmark, and Austria have shown strong support for populist parties and/or their candidates, as indicated by the proportion of voters who sympathized with the Swedish Democrats (I2.9\%), the Finns (I7.7\%), the Law and Justice Party (5I.5\%), the Danish People's Party (21.1\%), or the Freedom Party of Austria (49.7\%). Many authors are trying to identify the reasons for this growing success of populist parties (Albertazzi \& McDonnell, 2008a; Mény \& Surel, 2002; Mudde, 2004). Voting for specific parties that are a priori categorized as populist has lately been connected with a set of populist attitudes. These attitudes have been found

All correspondence concerning this article should be addressed to Anne Schulz, Universität Zürich, IPMZ, Andreasstrasse 15, 8050 Zürich. E-mail: a.schulz@ipmz.uzh.ch 
to correlate positively with support for populist parties and movements (Akkerman, Mudde, \& Zaslove, 20ı4; Hawkins, Riding, \& Mudde, 20I2; Hawkins \& Rovira Kaltwasser, 20I4). In research to date, populist attitudes have been conceptualized as a unidimensional measure. However, we argue that a unidimensional model fails to adequately describe populist attitudes, as it does not account for the different political ideas that have been identified as distinct yet correlated facets of a populist ideology (Mudde, 2004). Therefore, the present study proposes and tests a three-dimensional hierarchical measurement of populist attitudes. Such a three-dimensional model is not only able to identify populist attitudes in its entirety (i.e., attitudes indicating strong support for all three dimensions) but can also distinguish between different varieties of populist support (i.e., attitudes strongly supporting only one or two dimensions).

\section{Populism as an Ideology}

Authors frequently argue that populism is a "notoriously vague term" (Canovan, I999, p. 3), which entails a certain “conceptual slipperiness” (Taggart, 2000, p. I). Most recently, populism has been defined as a communication style (Jagers \& Walgrave, 2007), a political strategy (Weyland, 200I), and a political ideology (Mudde, 2004). This study takes the last perspective, defining populism as a "thincentred ideology" (Mudde, 2004, p. 544) comprising a "set of political ideas" (Hawkins 20I0, p. 5) about the structure of power in society (Albertazzi \& McDonnell, 2008b). More precisely, according to the populist ideology, society has a Manichean structure, as it is "ultimately separated into two homogeneous and antagonistic groups, 'the pure people' versus the 'corrupt elite,"' and politics is nothing but "an expression of the general will of the people" (Mudde, 2004, p. 543). With that, populism is defined as a thin-centered ideology, which can become a thickcentered ideology when it is combined with more complete ideologies, such as nativism—right-wing populism—or socialism—left-wing populism (Mudde \& Rovira Kaltwasser 2013). From this definition, we extract three political ideas that together form populism: (I) an anti-elitism approach, with elites seen as corrupt, betraying, and deceiving the people; (2) a belief in unrestricted popular sovereignty that leaves the power to the people; and (3) an understanding of the people as being homogenous and virtuous (Wirth et al., 20I6). When populism is conceived of as a set of political ideas or as a multidimensional construct, researchers should operationalize and measure populist attitudes accordingly. In the following section, we argue that this has not been followed with sufficient diligence in prior research on populist attitudes among the general public.

Aside from two early attempts at the end of the twentieth century to identify populist attitudes within the United States (Axelrod, I967; Farrell \& Laughin, I976), it has only been recently that populist attitudes have received significant attention from researchers. Akkerman et al., (20I4; see also Hawkins et al., 20I2) developed a one-dimensional conceptualization of populist attitudes. This measure reflects two of the three key elements of populism identified above: popular sovereignty and an antagonism toward what is perceived to be an evil political elite. This instrument has been tested in the United States (Hawkins et al., 20I2), the Netherlands (Akkerman et al., 20I4), Chile (Hawkins \& Rovira Kaltwasser, 20I4), 
and recently also in Flanders (Spruyt, Keppens, \& van Droogenbroeck, 20I6). The inventory comprises six items measuring populist attitudes (e.g., "The politicians in Congress need to follow the will of the people"). These researchers used principle component analysis to demonstrate that populist attitudes form a single dimension distinct from elitist and pluralist attitudes toward democracy. The successful replication of the model in three different countries leads to the conclusion that "populist attitudes are widespread and latent” (Hawkins \& Rovira Kaltwasser, 20I4, p. 5). In a construct validity test, the authors correlated the populism measure with demographic, social, and political indicators. In the Chilean case affiliates of leftist parties showed stronger populist attitudes compared with partisans of rightist parties. However, populist attitudes were unrelated to demographics (Hawkins \& Rovira Kaltwasser, 20I4). In the Netherlands, populist attitudes were correlated with support for parties that are often categorized as populist (i.e., the Socialist Party and the Party for Freedom) (Akkerman et al., 20I4). Additionally, it was shown that in the United States, populist attitudes correlate positively with strong affiliations to either liberal or conservative ideologies (Akkerman et al., 20I4). A strength of these papers was to show that populism is a concept that is distinct from other political ideologies, such as elitism and pluralism. However, two problems with this conceptualization remain. First, it lacks to depict the idea of the people as a homogenous group that is wise and virtuous. Homogeneity and virtuousness are essential to the definition of populism as used in this research as well as in prior studies. Taggart (2000) stresses the importance of this idea by declaring the people as "the defining feature of populism" (p. 9I; emphasis in original). Following his explications and those of others, this central feature of populism encloses more than the demand for popular sovereignty. This aspect of people-centrism entails an understanding of a monolithic people that is altogether good, honest, and upright. In this vein, the people share the same values and interests. In addition, the people is seen as a coherent entity ready to withstand any external threats (Albertazzi \& McDonnell, 2008a; Mudde, 2004). A measurement that fails to consider this dimension is unable to fully grasp thin-centered populism. Second, because of this conceptualization's unidimensionality, it is impossible to detect varieties of populist attitudes, such as the branch of populist thinking that predominantly promotes the notion of a reified popular will and is less intensely attached to the notion of a conspiring elite.

\section{A Three-Dimensional Construct}

Building on the prior research outlined in the preceding section, the present article aims to develop a more finely grained inventory with which to measure the concept of populism. Previous reasoning on populism suggests that the populist ideology is built on three main political ideas. If we wish to measure the degree of individual support of populism, an instrument is needed that delineates between support for each of these three ideas. When a full populist is assumed to hold strong anti-elitism attitudes, a strong belief in unrestricted popular sovereignty, and an understanding of the people as being homogenous and virtuous, then populist attitudes can be conceptualized as a second-order factor made up of these three distinct sub-dimensions as first-order factors. 
There are several reasons to suggest a three-dimensional structure of populist attitudes. First, the empirical measurement of a construct of interest should reflect all facets that are derived from the underlying theory. When populist attitudes are defined by three elements, then it is reasonable to expect three dimensions that are part of a higher-order latent construct that represents populist attitudes. If one dimension was to be missing from the operationalization, the measurement would not reflect all facets of populist attitudes, but rather an incomplete version of the ideology. Second, if populism is conceptualized as a three-dimensional construct, then these attitude dimensions can be activated in varying degrees in an individual mind. For example, although there may be many people who hold anti-elitism attitudes, not all of them favor popular sovereignty or perceive the people as a homogenous and virtuous group. This reality is not reflected in a one-dimensional measure, which treats individuals scoring high on one dimension as both, similar to individuals scoring high on another dimension and to individuals scoring moderately on all dimensions. Applying this logic, people who hold anti-elitism attitudes but who do not see direct democratic procedures as a solution to compensate for the wrongdoings of the political elite would be indistinguishable from individuals who show the opposite pattern of attitudes - that is, who do not see the political elite as corrupt, but who favor direct democracy. In treating populist attitudes as a single dimension, researchers cannot distinguish between these two different views on politics. In contrast, a three-dimensional measurement would enable the researcher to detect these different attitude patterns.

The third advantage of a three-dimensional measurement is the more precise predictions it allows researchers to make. In the example given in the preceding paragraph-describing people who hold anti-elitism attitudes yet who do not demand popular sovereignty - the degree of populism within a given society could easily be overestimated if a one-dimensional measure was used. Such an instrument could identify individuals as populists even if they were in fact only dissatisfied with the work of the current government. In contrast, an instrument based on a three-dimensional conceptualization would require that individuals score sufficiently high on all three dimensions to be considered to hold populist attitudes. Therefore, our assumption is that populist attitudes are a latent second-order construct made up of three lower-order dimensions: anti-elitism attitudes, a preference for unrestricted popular sovereignty, and a belief in the homogeneity and virtuousness of the people. We will test this assumption on the basis of two separate data sets using exploratory and confirmative factor analysis. To provide further evidence of construct validity, we will include measures of elitist and pluralist attitudes into our analysis and contrast these to the three populist attitude dimensions proposed before.

\section{Method}

\section{Data and Procedure}

To develop a scale for the three-dimensional structure of populist attitudes, two surveys were conducted over the course of 6 months. The first study was an online survey conducted in December 2014 on a nation-wide sample of Swiss respondents $(N=400)$. The second survey was conducted online in April 2015, but 
based on a Swiss sample only taken from the city of Zurich and its surrounding regions $(N=\mathrm{I}, 260)$. In both studies, samples were recruited from online access panels, applying a quota procedure with regard to age and gender. These samples approach the population of interest's characteristics in terms of age (national sample: $M=43.7 \mathrm{I} ; S D=\mathrm{I} 5.57$; regional sample: $M={ }_{5} \mathrm{I} .86 ; S D=\mathrm{I} 3.80$ ) and gender (national sample: $50 \%$ female; regional sample: $47.1 \%$ female).

\section{Measurement}

We examined populist attitudes by measuring three sub-dimensions: anti-elitism attitudes, demand for popular sovereignty, and belief in the homogeneity and virtuousness of the people. The initial item pool comprised $2 \mathrm{I}$ items that were assumed to reflect the three dimensions. Most of these items were taken from previous studies and, thus, depicted anti-elitism and people's sovereignty (Akkerman et al., 20I4; Hawkins et al., 20I2; Hawkins \& Rovira Kaltwasser, 20I4). A literature review and a preliminary analysis of news coverage containing populist communication led to additional items tracing these two dimensions. This resulted in nine items reflecting anti-elitism attitudes (anti) and another six items reflecting a demand for popular sovereignty (sov). After consulting literature on the perception of in-group homogeneity and entitativity (Carpenter \& Radhakrishnan, 2002; Lickel at al., 2000; Quattrone \& Jones, I980), six items were chosen to assess the belief in a homogeneous and virtuous people (hom). Across all three dimensions, various items depict the Manichean perspective of populism by setting the entity of "the people" against the entity of "the politicians" or the "government." Survey participants rated all items using 5-point Likert scales ranging from $\mathrm{I}=$ strongly disagree to $5=$ strongly agree (see Supplementary Tables $A_{I}$ and $A_{3}$ for question wording in English and German).

Elitist attitudes were measured relying on three items that were taken from the existing literature (Akkerman et al., 20I4; Hawkins \& Rovira Kaltwasser, 20I4). Partially, these items were rephrased to consistently refer to the idea that the political elite (i.e., "the government" or "politicians") is in charge of important decisions and not educated experts (i.e., "independent experts" and "successful business people"). Pluralist attitudes were measured using four items. Two indicators were taken from previous studies (Akkerman et al., 20I4; Hawkins \& Rovira Kaltwasser, 20I4), and two items were added to also depict acknowledgment of minority views and opposing views in society (see Supplementary Table A2 for question wording).

\section{Results}

The 2 I items from the populism scale were submitted to an exploratory factor analysis (EFA) using the promax rotation method. The results of the factor analysis relying on the data from the national sample revealed a three-dimensional structure. To optimize the solution, items were excluded when communalities or factor loadings were too low or when items loaded on more than one factor. This process was then stopped before factors reached an item number lower than four. At the end of this process, ${ }_{5} 5$ items remained: five items that reflect an anti-elitism attitude, four items that refer to the 
sovereignty of the people, and six items that expressed a belief in a homogeneous and virtuous people. These items share variance to a high degree $(\mathrm{KMO}=0.89)$. The three factors together account for $55 \%$ of the variance (Factor $\mathrm{I}=35 \%$; Factor $2=$ I $2 \%$; Factor $3=8 \%$, eigenvalues $=5.68,2.26$, I.59, respectively). Factor loadings ranged between .632 and .896 . Homogeneity items loaded strongly on the first factor, anti-elitism items on the second factor, and sovereignty items on the third factor. No serious cross-loadings occurred, and reliability was satisfactory for all three factors (see Supplementary Table Aı, also for communalities, mean values, and $S D$ s). Using the data from the regional sample, the analysis was replicated and resulted in the same factor structure (Supplementary Table A2). Thus, preliminary exploratory factor analyses support the assumed three-dimensional structure of populist attitudes. Interestingly, these analyses led to the exclusion of some of the items used in previous studies (Akkerman et al., 20I4; Hawkins et al., 20I2, 20I4); these items were all replaced by new items. However, four of six items (items 2, 5, 8, and 9) used in prior studies were retained in the updated version of the measure.

To test the robustness of this factor structure, the dimensionality of populist attitudes was further examined in a confirmatory factor analysis (CFA) using the $\mathrm{R}$ 3.2.0 package lavaan (Rosseel, 20I2). This was done for both the national and regional sample. Populist attitudes were modeled as a second-order factor with three proposed distinct sub-dimensions. Items were permitted to load only on the factors they were expected to load on. A first test of a three-dimensional second-order factor model with the national data indicated an acceptable fit $\left(\chi^{2}=2\right.$ I0.7, $d f=87, p \leq .00$; comparative fit index $=0.954$; root mean squared error of approximation $=0.06$ ) . To improve model fit, modification indices were examined. The output indicated that three items caused problems (i.e., high covariation with other items on their factor and even with items across factors). These three items were excluded from the analysis. The resulting model showed a better fit to our data (Table I, Panel A). All items load substantially (loadings higher than .5 in all cases) on their hypothesized latent factors. Furthermore, the latent first-order factors show significant loadings on the proposed second-order factor that represents populist attitudes (Table I, Panel B). This result is in line with the hypothesis that populist attitudes are a latent higherorder construct made up of the three lower-order dimensions of anti-elitism attitudes, a preference for unrestricted popular sovereignty, and a belief in the homogeneity and virtuousness of the people.

To further corroborate the validity of this conceptualization of populist attitudes, two additional steps were taken. First, the three-dimensional second-order factor model was compared with two one-dimensional models of populist attitudes. The first single-factor model included the six items from Akkerman et al. (20I4). As we have implemented the full six-item set only in the national survey, the model could only be estimated for this data set. The second one-dimensional model used the I2item set introduced above. This model was estimated on the basis of both available data sets. These one-factor models assume that the covariance among the items can be accounted for by a single latent variable, as implied by existing operationalizations of populist attitudes (Hawkins et al., 20I2). The fit statistics in Panel A of Table I indicate that a hierarchical multidimensional model of populist attitudes is superior to all three one-dimensional models. 
Second, we used 12 populism items from the regional data set to test whether populism, elitism, and pluralism are distinct constructs. This analysis resulted in five factors, each of which always only comprised items of one specific construct with loadings higher than .539 and cross-loadings lower than .2 (see Supplementary Table A2). Finally, CFA yielded that both, elitism and pluralism, correlate negatively with all three sub-dimensions that we have conceptualized (anti-elitism and elitism: $r=$ $-.5_{5}, p<.00 \mathrm{I}$; anti-elitism and pluralism: $r=-.04, p<.05$; sovereignty and elitism: $r=-.35, p<.00 \mathrm{I}$; sovereignty and pluralism: $r=-.03 ; p=.07$; homogeneity and elitism: $r=-.07, p=.00 \mathrm{I}$; homogeneity and pluralism: $r=-.09, p<.00 \mathrm{I} ; N=$ I,260). In sum, the more participants agreed to either one of the three populism dimensions, the less they endorsed elitist or pluralist attitudes. These results provide evidence that the present threefold conception of populism is a valid construct that is distinct from other conceptions of democracy, that is, elitism and pluralism.

\section{Discussion}

Research on measuring populism in public opinion surveys has grown in the past decade because of the rise of populist parties in Western democracies. The present article introduces a refined instrument for measuring populist attitudes. From extant definitions of populism as a thin ideology, we inferred three dimensions: an anti-elitism approach, the belief in unrestricted popular sovereignty, and an understanding of the people as being homogenous and virtuous. A rigorous empirical test using different data sets clearly demonstrates that a second-order model with three dimensions of populism is superior to a one-dimensional conceptualization in a number of ways.

First, as our major goal was to create a theoretically sound and exhaustive instrument to measure populist attitudes, we followed a deductive approach: operationalization was strictly derived from a broadly accepted definition of populism, from which the three most important notions underlying the theoretical concept were extracted. Second, the robustness of the three-dimensional second-order factor model was successfully tested using CFA. In prior studies, only exploratory factor analyses were used. However, EFA is not suitable for construct validity testing. All items are assumed to load on all factors, making CFA more appropriate for testing hypotheses that incorporate the dimensionality of populist attitudes. The analysis revealed three distinct dimensions that are positively correlated with each other and belong to one higher-order latent construct - that is, populist attitudes. Third, the successful replication of the model in two independent samples - the findings from both the national and regional samples confirmed the hypothesized model structure-further increases the credibility of the present approach. Fourth, in a final step of validation, we showed that all three populist attitude dimensions are also distinct from elitist and pluralist attitudes.

Finally, looking at possible applications of this instrument in future research, this tool allows researchers to investigate specific research questions. Researchers may want to examine to what extent affiliation to populist parties stems from anti-elitism attitudes, a general support of the idea of popular sovereignty, the perception of the people as homogenous and virtuous, or a combination of these dimensions. Prediction of vote choice can be further improved by adding a specific political ideology (i.e., left 
RESEARCH NOTE

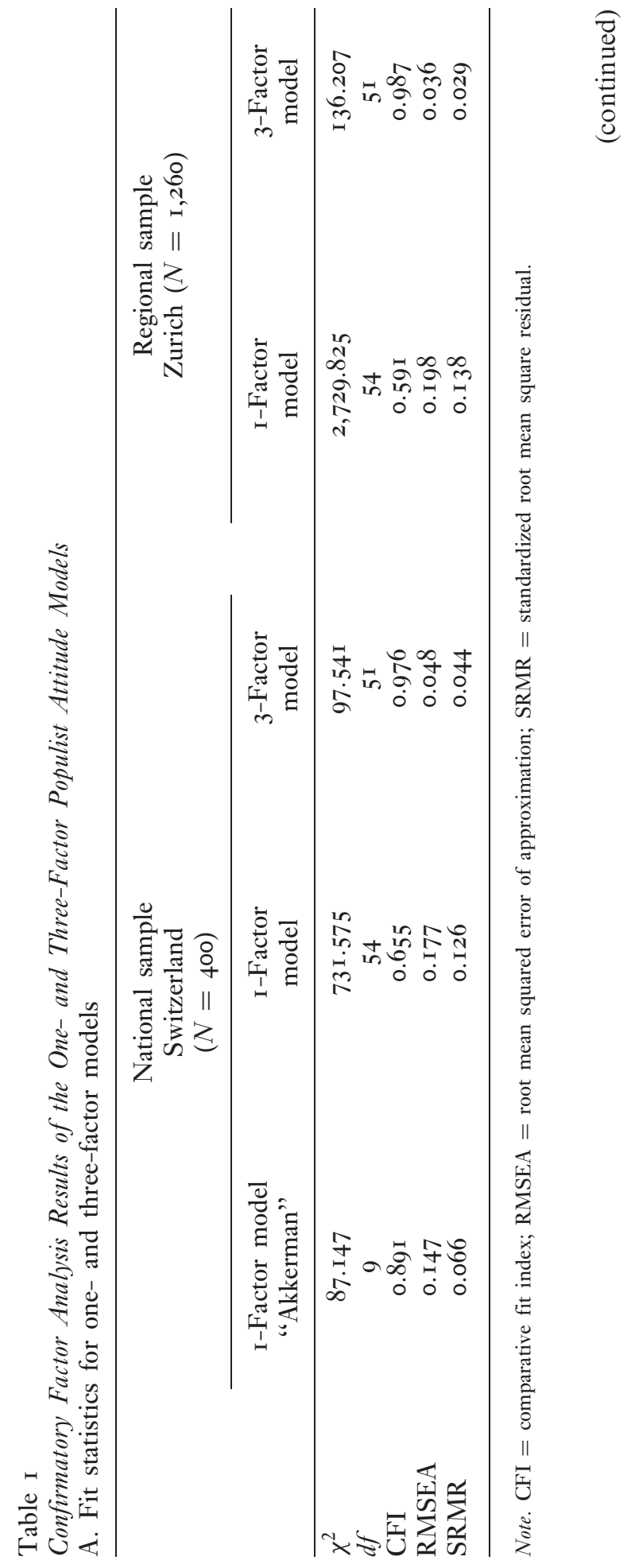


324 INTERNATIONAL JOURNAL OF PUBLIC OPINION RESEARCH

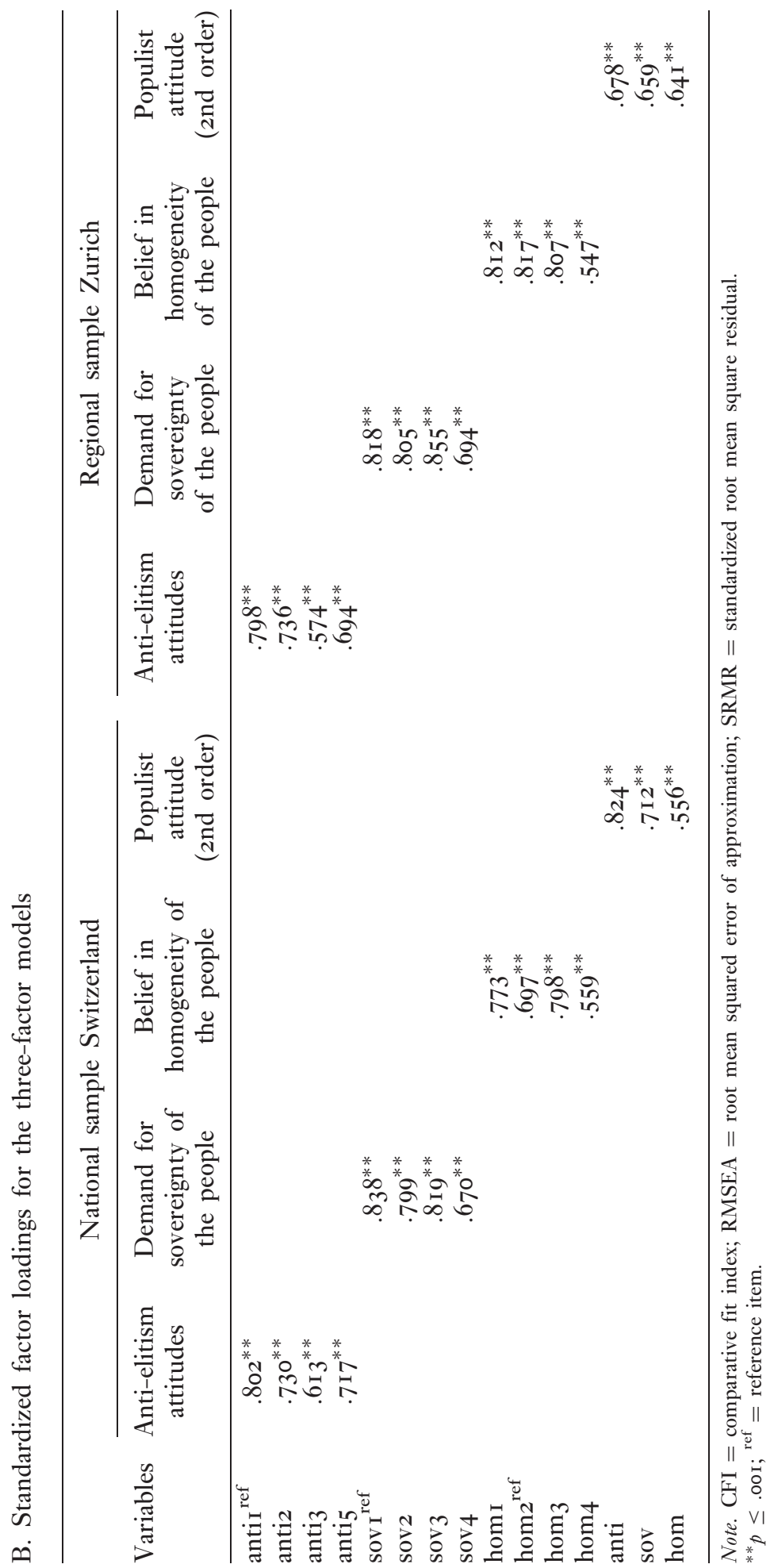


or right wing) as a fourth dimension to the model. The three dimensions measure the thin-centered ideology of populism; yet, the model is flexible enough to be extended to measure thick forms of populism as well. Furthermore, regarding a large corpus of research dealing with populist communication in media content (Akkerman, 20I I; Bos, van der Brug, \& de Vreese, 20Iı; Rooduijn, 20ı4; Wirth et al., 20I6), this new instrument enables researchers to trace specific communication effects on the three attitude dimensions, as not all populist statements found in the media will influence all of the three dimensions in the same way.

The present analysis also carries limitations. Data were collected using online access panels from only one country, and online surveys always carry a high risk of participants being distracted while filling out the questionnaire or quickly clicking through the questions without paying real attention to the content. We therefore recommend that future studies replicate the present findings using different samples and survey modes. Furthermore, this study was conducted in Switzerland, where a direct democracy is practiced. As this is exceptional among Western democracies, the instrument-developed for international research — should be tested in other countries as well. Moreover, we did not study how populist attitudes are related to vote choice or sociodemographic variables. Thus, another avenue for follow-up research would be to look at how the updated measure predicts vote choice or party affiliation, further corroborating the construct validity of the present measure.

\section{Supplementary Data}

Supplementary Data are available at IJPOR online.

\section{Funding}

This research is funded by the Swiss National Science Foundation.

\section{References}

Akkerman, T. (20II). Friend or foe? Right-wing populism and the popular press in Britain and the Netherlands. Fournalism, I2(8), 93I-945. doi: Io.II77/ I 4648849 I I 4I 5972

Akkerman, A., Mudde, C., \& Zaslove, A. (20I4). How populist are the people? Measuring populist attitudes in voters. Comparative Political Studies, 47(9), I324I353. doi: IO. I I77/o0I04I40I35I2600

Albertazzi, D., \& McDonnell, D. (Eds.). (2008a). Tonenty-first century populism: The spectre of Western European democracy. Basingstoke, UK: Palgrave.

Albertazzi, D., \& McDonnell, D. (Eds.). (2008b). Introduction: The scepter and the spectre. In Twenty-first century populism: The spectre of Western European democracy (pp. I-I I). Basingstoke, UK: Palgrave.

Axelrod, R. (1967). The structure of public opinion on policy issues. Public Opinion Quarterly, 3I(I), 5I-6o. doi:Io.Io86/26748 I

Bos, L., van der Brug, W., \& de Vreese, C. (20I I). How the media shape perceptions of right-wing populist leaders. Political Communication, 28(2), I82-206. doi:I0.1080/ I0584609.20 I I.564605 
Canovan, M. (I999). Trust the people! Populism and the two faces of democracy. Political Studies, 47(I), 2-I6. doi: Io. I I I/ I467-9248.00г 84

Carpenter, S., \& Radhakrishnan, P. (2002). The relation between allocentrism and perceptions of ingroups. Personality and Social Psychological Bulletin, 28, I 528-I 537. doi: го. I 77 /о I 46 г6702237580

Farrell, J. J., \& Laughin, P. R. (1976). A scale to measure populist attitudes. The Fournal of Psychology, 94, 33-38. doi: го. 1080/00223980.1976.992 г392

Hawkins, K. A. (2010). Venezuela's Chavismo and populism in comparative perspective. Cambridge, UK: Cambridge University Press.

Hawkins, K. A., Riding S., \& Mudde, C. (20I2). Measuring populist attitudes. Political concepts committee on concepts and methods morking paper series, 55, I-35.

Hawkins, K. A., \& Rovira Kaltwasser, C. (20I4). The populist specter in contemporary Chile. Paper presented at the 20I4 Latin American Studies Association (LASA), Chicago, IL.

Jagers, J., \& Walgrave, S. (2007). Populism as political communication style: An empirical study of political parties' discourse in Belgium. European Fournal of

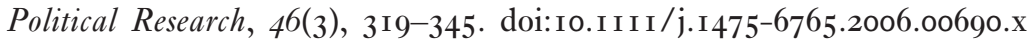

Lickel, B., Hamilton, D. L., Wieczorkowska, G., Lewis, A., Sherman, S. J., \& Uhles, A. N. (2000). Varieties of groups and the perception of entitativity. Fournal of Personality and Social Psychology, 78, 223-246. doi:Io.I037/0022-35I4.78.2.223

Mény, Y., \& Surel, Y. (2002). Democracies and the populist challenge. New York, NY: Palgrave.

Mudde, C. (2004). The populist zeitgeist. Government and Opposition, 39(4), 54I-563. doi: Io. I I I /j. I 477-7053.2004.00I35.X

Mudde, C., \& Rovira Kaltwasser, C. (20I3). Populism and leadership. In P. 't Hart \& R. Rhodes (Eds.), Oxford handbook of political leadership (pp. 493-5I2). Oxford, UK: Oxford University Press.

Quattrone, G. A., \& Jones, E. E. (I980). The perception of variability within ingroups and out-groups: Implications for the law of small numbers. Fournal of Personality and Social Psychology, 38(I), I4I-I52. doi:Io. I037/0022-35I4-38.I.I4I

Rooduijn, M. (2014). The mesmerising message: The diffusion of populism in public debates in Western European media. Political Studies, 62(4), 726-744. doi:Io.I I I / I $467-9248$. I 2074

Rosseel, Y. (2012). lavaan: An R package for structural equation modeling. Fournal of Statistical Software, 48(2), I-36. http://www.jstatsoft.org/v48/ioz/

Spruyt, B., Keppens, G. \& van Droogenbroeck, F. (2016). Who supports populism and what attracts people to it? Political Research Quarterly, 69(2), 335-346. doi: Iо. I 177/ го659 г 29 г6639 г38

Taggart, P. (2000). Populism. Buckingham, PA: Open University Press.

Weyland, K. (200I). Clarifying a contested concept: Populism in the study of Latin American politics. Comparative Politics, 24, I-22. doi: I0.2307/4224I2

Wirth, W., Esser, F., Wettstein, M., Engesser, S., Wirz, D., Schulz, A... \& Schemer, C. (2016). The appeal of populist ideas, strategies and styles: A theoretical model and research design for analyzing populist political communication. Retrieved from http://www.nccr-democracy.uzh.ch/publications/workingpaper/pdf/wp_88. pdf 